\title{
二次元モデルを用いたパイオペースメーカー作成に関する基磷的研究
}

\section{Research for making bio pacemaker using computer simulation analysis}

○尾崎 葵、稲田 慎*、三井 和幸、柴田 仁太郎**、

Mark R. Boyett*、本荘 晴朗***、神谷 香一郎***、坚玉 逸雄***

東京電機大学大学院工学研究科精密システム工学専攻、*マンチェスター大学心血管内分泌科学、

**東京都保険医療公社大久保病院内科、 $* * *$ 名古屋大学環境医学研究所

AOI OZAKI, SHIN INADA*, KAZUYUKI MITSUI, NITARO SHIBATA**, MARK R. BOYETT*, HARUO HONJO***, KAICHIRO KAMIYA***, ITSUO KODAMA***

Department of Precision Engineering, Graduate school of Engineering, Tokyo Denki University

${ }^{*}$ Division of Cardiovascular and Endocrine Sciences, University of Manchester

** Tokyo Metropolitan Health and Medical Treatment Corporation Ohkubo Hospital

*** Research Institute of Environmental Medicine, Nagoya University

\section{1. 背量}

近年、細胞組織工学の進歩に伴い、収縮能力しか持たない 心筋組織に自発興奮を発生する細胞を移植することにより、 徐脈性不整脈を治療する試み（バイオペースメーカー）が行 われている。しかし、移植された紐胞が周囲の心笳組織を生 体のように有効に電気駆動することは困難であるため、我々 は心䑏自動能の興变発生及びその心筋への興罊伝播メカニ ズムをコンピュータシミュレーションシステムで検討して いる。本研究では洞結節細胞と心房筋細胞の接合面積に着目 し、心房筋駆動の有無や興奮伝達効率について検討した。

\section{2. シミュレーション条件}

層数 40 層（4681 ニニット）の六角形モデルにおいて、洞 結節領域中心 20 層（1141 ユニット）、心房筋領域外周 20 層 （3540ユニット）とし、洞結節領域と心房筋領域の接合面積 を徐々に隇少させた。使用モデルは洞結節構成条件を変え 2 パターン用意し、(1)膜容量 $\mathrm{Cm}$ の小さな細胞が多く分布する パターン及び2膜容量 $\mathrm{Cm}$ の大きな緗胞が多く分布するパタ ーンとした。

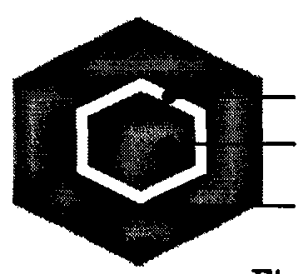
joint area sinus node atrial muscle
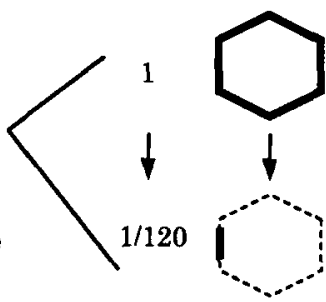

Fig. 1 simulation model
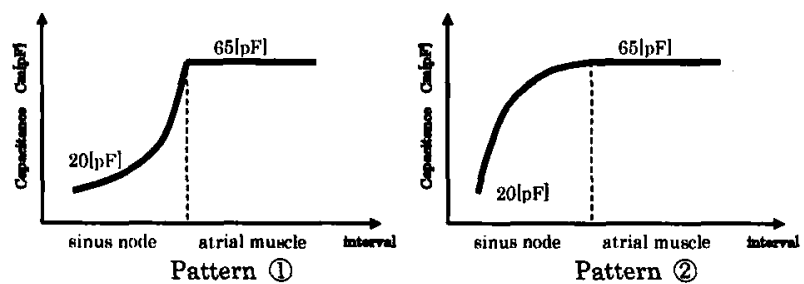

Fig. 2 Two kinds of distribution patterns of $\mathrm{Cm}$ set up in the model
3. シミュレーション結果

パターン(1)・(2)ともに接合面から最も離れている洞結節部 位から興奮が発生した。また接合面の結合コンダクタンス值 が十分であれば、興堛は心房筋へ安定した状態で伝播した。

パターン(1)では接合領域の減少に伴い興賈発生周期 CL が 徐々に短縮されていき、接合面積 6 分の 1 で $\mathrm{CL}=183[\mathrm{~ms}]$ 最 小となった。しかし接合領域 120 分の 1 以下で洞結節から発 生した興奮は心房筋へ伝播せず、いわゆる洞房ブロック状態 となった。

パターン(2)では接合面積が 12 分の 1 以下になるまで興奮 発生周期が安定せず、接合面積 12 分の 1 ので $\mathrm{CL}=178[\mathrm{~ms}]$ 最 小となった。また、洞結節から発生した興窑は、数 $[\mathrm{ms}]$ の遅 延はみられたものの接合面積 120 分の 1 の時でも比較的安定 した状態で心房筋へ伝播・駆動させることが可能であった。

\section{4. 考察}

心房筋からの電気緊張効果は、洞結節細胞と心房筋細胞が 接合されている部位で生じる。今回のように、接合部位を一 部のみとした場合、接合面から洞結節中心部へ向から力が一 方向へしか作用しないために、興奮発生部位が接合面とは反 对側の洞結節辺縁部へシフトしたと考えられる。また、パタ ーン(2)は接合面積を小さくしても比較的安定した状態で心 房筋を駆動させたことから、洞結節細胞は大きめの細胞で構 成した方がよいと考えられる。

\section{5. 結語}

本研究では洞結節細胞と心房筋細胞の接合面積に着目し、 心房筋駆動の有無や興奪伝達効率について検討を行った。そ の結果、洞結節細胞は電気的駆動力の大きい細胞で構成し、 且つ接合面積を小さくした方が、より速い自動能を得ること ができる可能性を示した。 